\title{
Financial Performance Measurement of Logistics Companies Based on Entropy and Waspas Methods
}

\author{
Hilal H. ERDOĞAN iD a Gökhan KIRBAÇ iD b \\ a Avrasya University, Trabzon, Turkey. hilal.erdogan@avrasya.edu.tr \\ b İstanbul Kültür University, İstanbul, Turkey. g.kirbac@iku.edu.tr
}

\begin{tabular}{|c|c|}
\hline ARTICLE INFO & ABSTRACT \\
\hline Keywords: & Purpose - The aim of this study is to measure financial performance of the logistics companies in the Fortune \\
\hline $\begin{array}{l}\text { Financial performance } \\
\text { Logistics performance }\end{array}$ & $\begin{array}{l}500 \text { list. Companies' financials are used to enlighten the logistics sector and supply chain operations by } \\
\text { revealing the developments between } 2015 \text { and } 2019 \text {. }\end{array}$ \\
\hline $\begin{array}{l}\text { Supply chain } \\
\text { Entropy weights } \\
\text { WASPAS }\end{array}$ & $\begin{array}{l}\text { Design/Methodology/Approach - The performance of the companies is evaluated by utilizing multi-criteria } \\
\text { decision-making techniques. As the best performance criteria affecting the companies' performance is } \\
\text { determined by Entropy Method, the company with the best performance is determined by WASPAS } \\
\text { Method. Selected financial measurements are net sales, earnings before interest and taxes (EBIT), total assets, total } \\
\text { equity, and the amount of export. }\end{array}$ \\
\hline $\begin{array}{l}2020 \\
\text { Revised } 21 \text { May } 2021 \\
\text { Accepted } 1 \text { June } 2021\end{array}$ & $\begin{array}{l}\text { Findings - It can be reached from the results that Export was determined as the best performance criteria } \\
\text { affecting the logistics companies' performance for all the years between } 2015 \text { and } 2019 \text {. On the other hand, } \\
\text { while Netlog is the best alternative in the year of 2015, } 2016 \text { and 2019, Borusan is the best alternative in the } \\
\text { year of } 2017 \text {. }\end{array}$ \\
\hline $\begin{array}{l}\text { Article Classification: } \\
\text { Research Article }\end{array}$ & $\begin{array}{l}\text { Discussion - Supply chain and logistics processes have critical importance in delivering the goods and } \\
\text { services of businesses to the final consumers. Hence, logistics companies need to determine performance } \\
\text { measurements while performing these services. It is believed that this study will be useful for the companies } \\
\text { who trade in different sectors and will contribute to the finance literature as a reference for further studies. } \\
\text { In this context, because of their quite comprehensive natures, both Entropy and WASPAS methods can be } \\
\text { conducted to any manufacturing-related decision-making processes. }\end{array}$ \\
\hline
\end{tabular}

\section{INTRODUCTION}

The concept of logistics is the set of services that enables businesses to deliver their goods or services to their final consumption points at the right place and time. Logistics is important both for businesses to ensure sustainable competition and for the continuity of production. Furthermore, in countries that are in the development process, the logistics sector creates significant economic impacts on the country's economy with the direction of employment, national income, and foreign investments. The main reason for the importance and large volume of the logistics sector can be stated as serving all sectors.

Therefore, logistics can be defined as the process of strategically controlling the supply, movement, and warehouse of materials, parts, finished inventory, and information flow through the organization and its marketing channels in a profitably way referring to current and future actions and this through cost-effective fulfillment of orders. With this explanation, logistics management means related to convincing the needs of customers across the managing of the materials and information flows that extend from the marketplace, through the company and its operations, and beyond that to suppliers (Christopher, 2011: 12).

To improve the efficiency of logistics sector, a performance measurement system plays an important role in providing the information for decision makers (Gunasekaran and Kobu, 2007: 2820). Therefore, the criteria that measure the companies' performance during their logistics and supply chain processes should be considered. To manage high-quality processes and to make effective decisions, various methods can be used. When several alternatives and criteria, jointly, are taken into account for complex decisions, multi-criteria decision-making techniques can be successfully applied (Zvadskas et al., 2012: 3). 


\section{H. H. Erdoğan - G. Kırbaç 13/2 (2021) 1093-1106}

Weighted Aggregated Sum Product Assessment (WASPAS) method is one of the best known and widely used multi-criteria decision-making technique to evaluate several alternatives concerning a set of decision criteria and can be applied not only for logistics companies but also for all businesses (Zvadskas et al., 2012; Chakraborty and Zavadskas, 2014). For instance, Zolfani et al. (2013) have specified that shopping malls are one of the singing of metropolises with their appealing shops. The Stepwise Weight Assessment Ratio Analysis (SWARA) and WASPAS methods have been used to evaluate potential alternatives. They have considered that Tehran is the main sample of this research and potential places and established a powerful framework in decision-making for solving locating issues in other companies. Ghorabaee et al. (2017) have stated that the selection of an appropriate Third Party Logistics (3PL) provider is a kind of Multi-Criteria Decision-Making problem. The 3PL providers with Interval Type-2 Fuzzy Sets (IT2FSs) have been evaluated by using a new integrated approach the Criteria Importance Through Inter-criteria Correlation (CRITIC) and WASPAS methods. The results prove the stability of ranking results and the efficiency of the proposed approach to handle Multi-Criteria Decision-Making problems with Interval Type-2 Fuzzy Sets. Bağcı and Yiğiter (2019) have analyzed the financial performances of energy companies traded on Borsa Istanbul between 2008 and 2017. Based on Standard Deviation (SD) and WASPAS methods, the company with high financial performance has changed every year. However, the company with the lowest financial performance is usually Akenerji. Xiong et al. (2020) have stated that the green supply chain management is a company's attempt to protect the environment and a main way to accomplish sustainable environmental development. It is proposed a hybrid method that integrates the Best-Worst method (BWM), WASPAS, and Technique for Order Preference by Similarity to Ideal Solution (TOPSIS) to solve the critical problems for green supply chain management. Combining the WASPAS and TOPSIS to reduce the uncertainty and inaccuracy in the decision-making process, it is found that the intuitionistic fuzzy number projects the preferences of the decision makers more exactly.

Entropy Method is often applied for determining the best performance criteria affecting the companies' performance, as well. Ulutaş (2019) has evaluated the performances of logistics firms listed on Fortune 500 by using Entropy and The Evaluation Based on Distance from Average Solution (EDAS) methods. Based on the results, while the best performance criterion is determined as "Export", the logistics company with the best performance is determined as "Mars" in 2017. Ayçin and Güçlü (2020), in their study, have analyzed the financial performances of the enterprises publicly traded on Borsa Istanbul by using Entropy and MAIRCA methods. According to the results, the best criteria affecting the performances were determined as current ratio, acid-test ratio, and asset turnover ratio. Furthermore, the enterprises with the highest financial performance are MILPA, SANKO and TEKNOSA, respectively. Özaydın and Karakul (2021) have used the Entropy weighted Multiple Attribute Utility Theory (MAUT), Simple Additive Weighting (SAW) and EDAS methods to measure the financial performance of companies operating in the food and drink sector. The shares of these companies are traded in Borsa Istanbul. According to the results, the ranking of the top five firms obtained by MAUT and EDAS are the same, while the ranking of the first five obtained by SAW differs in two firms.

Akçakanat et al. (2017) and Ural et al. (2018) have used both Entropy and WASPAS methods, in their study. Akçakanat et al. (2017) have evaluated the performances of small, medium, and large-sized banks based on the methods of Entropy and WASPAS for the first nine months of 2016. According to Entropy results, the number of branches is reported as the best performance criteria for all the banks. When the banks are ranked based on WASPAS results, it has resulted that Ziraat Bank, Finans Bank and Anadolu Bank are the best alternatives for large, medium, and small-sized banks, respectively. Ural et al. (2018) have analyzed the performances of three public banks operating in Turkey, covering the years from 2012 to 2016. When the performance evaluation criteria ranked based on the Entropy method, the number of branches is the best performing criteria for 2012, 2013 and 2014, consistent with the study of Akçakanat et al. (2017). On the other hand, paid-in capital is the best performing criteria for the years 2015 and 2016. When the public banks ranked based on WASPAS Method, Vakıf Bank is the best alternative for the years 2012 and 2013, while Ziraat Bank is the best alternative for the years 2014, 2015 and 2016. Bağc1 and Kaygın (2020) have analyzed financial performances of holdings and investment companies traded on Borsa Istanbul between the years of 2000 and 2017. Based on Entropy results, dividend payout ratio, market value to book value ratio were reported as the best performance criteria during the period. The financial performances of the companies were measured by using ARAS and WASPAS methods. Spearman correlation analysis was also carried out to test the relation 
between the results of the methods and a positive and strong relation was observed between the methods of ARAS and WASPAS.

Reviewing the literature suggests that there is a gap dealing with financial performance measures in logistics and supply chain environment. Within this context, in this study, the financial performance measurements of the major logistics companies in Turkey are evaluated. This analysis aims to measure financial performances of the logistics companies and supply chain providers listed on the Fortune 500 between the years of 2015 and 2019. As suggested by Shannon (1948) and Zvadskas et al. (2012), multi-criteria decision-making techniques are used and while Entropy Method is utilized to determine the best performance criteria affecting the companies' performance, WASPAS Method is used to rank the companies based on their performances. The results are evaluated and analyzed in terms of the developments in the logistics sector and supply chain operations. This study contributes to the international literature in the field of logistics and supply chain by using different financial performance measurement indicators and thus, strengthens the empirical frameworks of the earlier studies. Within this context, the conceptual framework for performance measurements of logistics and supply chain is provided, at first. The methodologies based on the Entropy and WASPAS techniques are then explained and the findings obtained are stated in the discussion and conclusion part.

\section{PERFORMANCE MEASUREMENTS OF LOGISTICS}

Logistics and supply chain give a significant and positive impact on the competitiveness of the countries' economy. Therefore, the evaluation of logistics performance gives a valuable benchmark for the logistics industry to enhance the performance of the industry towards competitiveness. Thus, performance measurement is an extremely important process for logistics companies and their supply chain operations.

Table 1. Logistics Performance Measurements

\begin{tabular}{|c|c|c|c|c|}
\hline & $\begin{array}{l}\text { Financial } \\
\text { Measurements }\end{array}$ & $\begin{array}{l}\text { Productivity } \\
\text { Measurements }\end{array}$ & $\begin{array}{l}\text { Quality } \\
\text { Measurements }\end{array}$ & $\begin{array}{l}\text { Response Time } \\
\text { Measurements }\end{array}$ \\
\hline $\begin{array}{l}\text { Customer } \\
\text { Responsiveness }\end{array}$ & $\begin{array}{l}\text { Total responsiveness } \\
\text { cost }\end{array}$ & $\begin{array}{l}\text { Customer orders per } \\
\text { person hour }\end{array}$ & $\begin{array}{l}\text { Order entry } \\
\text { accuracy }\end{array}$ & $\begin{array}{l}\text { Order processing } \\
\text { time }\end{array}$ \\
\hline $\begin{array}{l}\text { Inventory } \\
\text { Planning and } \\
\text { Management }\end{array}$ & Total inventory cost & Inventory returns & Forecast accuracy & \\
\hline Supply Chain & $\begin{array}{l}\text { Total supply chain } \\
\text { cost }\end{array}$ & & $\begin{array}{l}\text { Perfect purchase } \\
\text { order percentage }\end{array}$ & $\begin{array}{l}\text { Purchase order } \\
\text { cycle time }\end{array}$ \\
\hline Transportation & $\begin{array}{l}\text { Total transportation } \\
\text { cost }\end{array}$ & $\begin{array}{l}\text { Container capacity } \\
\text { utilization }\end{array}$ & $\begin{array}{l}\text { On-time arrival } \\
\text { percentage }\end{array}$ & In-transit time \\
\hline Warehousing & $\begin{array}{l}\text { Total warehousing } \\
\text { cost }\end{array}$ & $\begin{array}{l}\text { Units per person } \\
\text { hour }\end{array}$ & $\begin{array}{l}\text { Inventory and } \\
\text { shipping } \\
\text { accuracy }\end{array}$ & $\begin{array}{l}\text { Warehouse order } \\
\text { cycle time }\end{array}$ \\
\hline $\begin{array}{l}\text { Total Logistics } \\
\text { Operations } \\
\end{array}$ & Total logistics costs & & $\begin{array}{l}\text { Perfect order } \\
\text { percentage }\end{array}$ & \\
\hline
\end{tabular}

Source: (Skowron-Grabowska, 2009).

Table 1 shows general and financial logistics performance measurements under certain classifications. These classifications are made as financial, productivity, quality, and response time. Considering all these measurement classifications, logistics companies should pay attention to these criteria to ensure organizational efficiency and sustainable competition in the market. The measurements mentioned in the financial criteria enable businesses to measure their performance levels while performing their logistics and supply chain processes. Here, processes and operations such as customer responsiveness, inventory planning and management, supply chain, transportation, warehousing and total logistics operations are used to fulfill these logistics performance measurements.

On the other hand, there are also some other main financial indicators for not only logistics companies but also all industries. Particularly, net sales is used as one of the key performance indicators in all industries, as in supply chain management (Beamon, 1999; Gunasekaran et al., 2001). Earnings Before Interest and Taxes (EBIT) is also frequently used as an indicator for measuring financial performance of a company's operations 
H. H. Erdoğan - G. Kirbaç 13/2 (2021) 1093-1106

(Strouhal et al., 2018). Within this context, financial measurements that express value for stakeholders such as customers, competitors, importers, suppliers, etc. in the logistics ecosystem are discussed. This is where the originality of the work comes into play in this part.

\section{METHODOLOGY}

The financial performance of the seven logistics companies (Mars, Ekol, Netlog, Reysaş, Borusan, Horoz, Alışan) was evaluated between 2015 and 2019 by utilizing multi-criteria decision-making techniques. As the best performance criteria affecting the companies' performance was determined by Entropy Method, the company with the best performance was determined by WASPAS Method. As financial performance measurement indicators, net sales, EBIT, total assets, total equity, and the amount of export, obtained from the official website of Fortune Turkey ${ }^{1}$, were selected.

\subsection{Entropy Method}

As suggested by Shannon (1948), Entropy is a fixed weight method that is applied to evaluate the decisionmaking process, and similarly, it can be used to provide the amount of useful information based on evaluation criteria weights for the alternatives.

To determine the objective weight of each criterion based on entropy method, the steps can be summarized as follows ( $\mathrm{Wu}$, et al., 2011: 5163):

Step 1. Construct a decision matrix: In the case of $m$ alternatives and $n$ evaluation criteria, the decision-making matrix is defined as follows:

$$
\left[\begin{array}{cccc}
x_{11} & x_{12} & \ldots & x_{1 n} \\
x_{21} & x_{22} & \ldots & x_{2 n} \\
\ldots & \ldots & \ldots & \ldots \\
x_{m 1} & x_{m 2} & \ldots & x_{m n}
\end{array}\right]
$$

Step 2. Normalize the decision matrix: The decision matrix is normalized for each criterion because of different scales of them, as in the following equation:

$$
P_{i j}=\frac{x_{i j}}{\sum_{j=1}^{m} x_{i j}} i=1,2, \ldots ., m j=1,2, \ldots ., n
$$

where $P_{i j}$ is normalized value, $x_{i j}$ is the value of projection.

Step 3. Determine the entropy value: Measurement of the entropy value for all criteria is expressed, after normalized the decision matrix, as:

$$
e_{j}=-k \sum_{j=1}^{m} P_{i j} \ln P_{i j}
$$

where $e_{j}$ is the entropy value of $j$.criterion, $k$ is the entropy constant and $0 \leq e j \leq 1$ is provided.

Step 4. Determine the degree of divergence: The degree of divergence for each criterion are calculated by using entropy value, as follows:

$$
d j=1-e j
$$

where $j$ is the degree of diversification.

Step 5. Determine the objective weight: The objective weight for each criterion is measured by the following equation:

$$
w_{j}=\frac{d_{j}}{\sum_{s=1}^{n} d_{s}} j=1,2, \ldots \ldots, n
$$

Where $w_{j}$ is the weight of $j$. criterion. The higher the entropy weight $\left(w_{j}\right)$, the more important and useful evaluation criterion for the decision-making process (Wang and Lee, 2009).

${ }^{1}$ https://www.fortuneturkey.com/fortune500 


\subsection{WASPAS Method}

The combination of two methods is proposed to increase the ranking accuracy and effectiveness of the decision-making process. The WASPAS Method is a unique combination of two well-known MCDM approaches, i.e. weighted sum model (WSM) and weighted product model (WPM). This is one of the best known and often applied multi-criteria decision-making techniques to evaluate several alternatives concerning a set of decision criteria (Zvadskas et al., 2012; Chakraborty and Zavadskas, 2014).

To determine the optimal alternative based on WASPAS Method, the steps can be summarized as follows (Zvadskas et al., 2012: 3; Chakraborty and Zavadskas, 2014: 3):

Step 1. Construct a decision matrix: In the case of $m$ alternatives and $n$ evaluation criteria, the decision-making matrix is defined as follows:

$$
\left[\begin{array}{cccc}
x_{11} & x_{12} & \ldots & x_{1 n} \\
x_{21} & x_{22} & \ldots & x_{2 n} \\
\ldots & \ldots & \ldots & \ldots \\
x_{m 1} & x_{m 2} & \ldots & x_{m n}
\end{array}\right]
$$

where $x_{i j}$ is the performance of $i^{\text {th }}$ alternative with respect to $j^{\text {th }}$ criterion.

Step 2. Normalize the decision matrix: All the criteria in the decision matrix are normalized using the following two equations:

for beneficial criteria;

$$
\bar{x}_{i j}=\frac{x_{i j}}{\max _{i} x_{i j}} i=1,2, \ldots ., m j=1,2, \ldots ., n
$$

for non-beneficial criteria;

$$
\bar{x}_{i j}=\frac{\min _{i} x_{i j}}{x_{i j}} i=1,2, \ldots, m j=1,2, \ldots, n
$$

where $\bar{x}_{i j}$ is the normalized value of $x_{i j}$.

Step 3. Construct The Weighted Sum Model / Determine The Relative Importance of Alternative based on WSM: According to WSM model, the total relative importance of $i^{\text {th }}$ alternative is evaluated as follows:

$$
Q_{i}^{(1)}=\sum_{j=1}^{n} \bar{x}_{i j} w_{j}
$$

where $w_{j}$ is the weight (relative importance) of $j^{\text {th }}$ criterion.

Step 4. Construct The Weighted Product Model: According to the WPM model, the total relative importance of $i^{\text {th }}$ alternative is expressed as below:

$$
Q_{i}^{(2)}=\prod_{j=1}^{n}\left(\bar{x}_{i j}\right)^{w_{j}}
$$

Step 5. Determine the total importance of the alternative: A joint generalized criterion for determining total importance of alternative of $i^{\text {th }}$ alternative is developed by the following equation:

$$
Q_{i}=0.5 Q_{i}^{(1)}+0.5 Q_{i}^{(2)}
$$

Step 6. Determine the total relative importance of the alternative: A more generalized equation for determining the total relative importance of $i^{\text {th }}$ alternative is developed as follows:

$$
Q_{i}=\lambda Q_{i}^{(1)}+(1-\lambda) Q_{i}^{(2)} \lambda=0,0.1, \ldots, 1
$$

When the value of $\lambda$ is equal to ' 0 ', WASPAS Method is transformed to the weighted product model (WPM), and when the value of $\lambda$ is equal to ' 1 ', it is transformed to the weighted sum model (WSM). The alternatives are ranked based on the $Q_{i}$ values and the highest $Q_{i}$ value is an indicator of the best alternative with respect to a set of decision criteria.

\section{EMPIRICAL FINDINGS}


H. H. Erdoğan - G. Kurbaç 13/2 (2021) 1093-1106

Table 2 reports the constructed decision matrix consisting of seven logistics companies and five financial evaluation criteria between the years of 2015 and 2019.

Table 2.Constructed Decision Matrix

\begin{tabular}{|c|c|c|c|c|c|}
\hline & Net Sales & EBIT & Total Assets & Total Equity & Export \\
\hline \multicolumn{6}{|c|}{2019} \\
\hline Mars & $1.824 .304 .256,00$ & $272.300 .992,00$ & $1.393 .745 .024,00$ & $972.661 .440,00$ & $596.614 .784,00$ \\
\hline Ekol & $3.341 .637 .376,00$ & $79.717 .128,00$ & $2.813 .050 .112,00$ & $468.627 .424,00$ & $2.343 .131 .392,00$ \\
\hline Netlog & $4.726 .777 .856,00$ & $438.503 .616,00$ & $3.140 .357 .376,00$ & $456.069 .408,00$ & $3.092 .561 .920,00$ \\
\hline Reysaş & $662.132 .352,00$ & $257.541 .328,00$ & $1.427 .043 .712,00$ & $63.378 .856,00$ & $79.520 .480,00$ \\
\hline Horoz & $774.753 .344,00$ & $28.725 .712,00$ & $493.151 .168,00$ & $98.758 .808,00$ & $131.200 .840,00$ \\
\hline Borusan & $2.523 .230 .208,00$ & $107.794 .192,00$ & $2.378 .316 .288,00$ & $764.727 .552,00$ & $390.281 .824,00$ \\
\hline Alışan & $725.925 .504,00$ & $110.910 .888,00$ & $647.757 .440,00$ & $115.372 .680,00$ & $103.534 .888,00$ \\
\hline \multicolumn{6}{|c|}{2018} \\
\hline Ekol & $3.329 .325 .176,00$ & $113.663 .194,00$ & $2.543 .748 .101,00$ & $442.006 .012,00$ & $2.666 .504 .964,00$ \\
\hline Reysaş & $541.498 .558,00$ & $377.290 .637,00$ & $1.377 .061 .871,00$ & $58.244 .921,00$ & $52.063 .376,00$ \\
\hline Horoz & $649.276 .198,00$ & $37.153 .916,00$ & $311.446 .189,00$ & $95.347 .268,00$ & $124.115 .793,00$ \\
\hline Alışan & $646.970 .527,00$ & $60.016 .926,00$ & $549.020 .364,00$ & $51.346 .972,00$ & $101.106 .164,00$ \\
\hline \multicolumn{6}{|c|}{2017} \\
\hline Mars & $1.059 .563 .875,00$ & $112.528 .008,00$ & $677.802 .883,00$ & $494.789 .587,00$ & $535.889 .746,00$ \\
\hline Ekol & $2.465 .900 .679,00$ & $25.120 .101,00$ & $1.680 .906 .560,00$ & $321.199 .931,00$ & $1.944 .136 .610,00$ \\
\hline Netlog & $2.358 .532 .579,00$ & $134.153 .501,00$ & $1.136 .119 .054,00$ & $167.172 .574,00$ & $1.523 .206 .634,00$ \\
\hline Reysaş & $449.649 .155,00$ & $129.205 .037,00$ & $1.304 .241 .551,00$ & $170.200 .790,00$ & $34.132 .205,00$ \\
\hline Horoz & $645.261 .227,00$ & $30.472 .028,00$ & $275.922 .601,00$ & $86.614 .089,00$ & $86.289 .468,00$ \\
\hline Borusan & $2.097 .023 .211,00$ & $138.355 .583,00$ & $1.570 .621 .453,00$ & $536.152 .544,00$ & $2.838 .663 .788,00$ \\
\hline Alişan & $460.764 .724,00$ & $20.686 .716,00$ & $415.794 .474,00$ & $34.889 .731,00$ & $74.581 .155,00$ \\
\hline \multicolumn{6}{|c|}{2016} \\
\hline Mars & $774.924 .734,00$ & $80.194 .928,00$ & $491.375 .983,00$ & $359.893 .799,00$ & $375.502 .557,00$ \\
\hline Ekol & $1.880 .452 .808,00$ & $50.263 .958,00$ & $1.318 .687 .489,00$ & $247.043 .821,00$ & $857.582 .949,00$ \\
\hline Netlog & $1.841 .634 .950,00$ & $100.580 .769,00$ & $1.067 .863 .413,00$ & $176.341 .407,00$ & $1.117 .689 .451,00$ \\
\hline Reysaş & $379.744 .743,00$ & $90.392 .897,00$ & $1.110 .314 .251,00$ & $192.132 .199,00$ & $19.872 .307,00$ \\
\hline Horoz & $595.847 .559,00$ & $26.525 .541,00$ & $251.372 .724,00$ & $72.901 .279,00$ & $66.541 .638,00$ \\
\hline Borusan & $1.562 .209 .370,00$ & $92.208 .085,00$ & $1.420 .639 .758,00$ & $456.453 .498,00$ & $231.582 .997,00$ \\
\hline Alişan & $375.164 .410,00$ & $32.730 .386,00$ & $369.358 .486,00$ & $40.567 .813,00$ & $66.551 .978,00$ \\
\hline \multicolumn{6}{|c|}{2015} \\
\hline Mars & $649.771 .437,00$ & $53.438 .788,00$ & $366.213 .098,00$ & $257.732 .761,00$ & $308.415 .152,00$ \\
\hline Ekol & $1.512 .011 .386,00$ & $49.112 .114,00$ & $1.023 .182 .758,00$ & $199.662 .615,00$ & $380.475 .336,00$ \\
\hline Netlog & $1.569 .737 .335,00$ & $67.935 .090,00$ & $920.253 .453,00$ & $161.297 .761,00$ & $924.591 .855,00$ \\
\hline Reysaş & $339.665 .751,00$ & $95.222 .736,00$ & $1.030 .629 .282,00$ & $240.496 .516,00$ & $15.468 .361,00$ \\
\hline Horoz & $554.521 .645,00$ & $23.053 .129,00$ & $196.079 .425,00$ & $10.950 .619,00$ & $60.144 .910,00$ \\
\hline Borusan & $1.411 .008 .151,00$ & $85.739 .162,00$ & $1.202 .841 .192,00$ & $338.463 .433,00$ & $170.263 .883,00$ \\
\hline Alışan & $355.136 .287,00$ & $30.498 .789,00$ & $249.391 .022,00$ & $23.133 .998,00$ & $59.829 .532,00$ \\
\hline
\end{tabular}

Source: (Fortune Turkey, 2020). *In the study, abbreviations are used for logistics company names. Mars Logistics Group Inc. (Mars), Ekol Logistics Inc. (Ekol), Netlog Logistics Services Inc. (Netlog), Reysaş Transportation and Logistics Trade Inc. (Reysaş), Horoz Logistics Cargo Services and Trade Inc. (Horoz), Borusan Logistics Distribution Warehousing Transportation and Trade Inc. (Borusan) and Alışan International Transportation Inc. (Alışan).

\subsection{Entropy Results}


H. H. Erdoğan - G. Kırbaç 13/2 (2021) 1093-1106

The decision matrix of seven logistics companies and five evaluation criteria are established according to the data in Table 2. The normalized decision matrix is established and reported on Table 3.

Table 3. Normalized Decision Matrix

\begin{tabular}{|c|c|c|c|c|c|}
\hline & Net Sales & EBIT & Total Assets & Total Equity & Export \\
\hline \multicolumn{6}{|c|}{2019} \\
\hline Mars & 0,1251 & 0,2102 & 0,1134 & 0,3309 & 0,0886 \\
\hline Ekol & 0,2292 & 0,0615 & 0,2288 & 0,1594 & 0,3478 \\
\hline Netlog & 0,3242 & 0,3385 & 0,2555 & 0,1551 & 0,4591 \\
\hline Reysaş & 0,0454 & 0,1988 & 0,1161 & 0,0216 & 0,0118 \\
\hline Horoz & 0,0531 & 0,0222 & 0,0401 & 0,0336 & 0,0195 \\
\hline Borusan & 0,1731 & 0,0832 & 0,1935 & 0,2601 & 0,0579 \\
\hline Alışan & 0,0498 & 0,0856 & 0,0527 & 0,0392 & 0,0154 \\
\hline \multicolumn{6}{|c|}{2018} \\
\hline Ekol & 0,6443 & 0,1933 & 0,5320 & 0,6832 & 0,9058 \\
\hline Reysaş & 0,1048 & 0,6415 & 0,2880 & 0,0900 & 0,0177 \\
\hline Horoz & 0,1257 & 0,0632 & 0,0651 & 0,1474 & 0,0422 \\
\hline Alışan & 0,1252 & 0,1020 & 0,1148 & 0,0794 & 0,0343 \\
\hline \multicolumn{6}{|c|}{2017} \\
\hline Mars & 0,1111 & 0,1906 & 0,0960 & 0,2732 & 0,0762 \\
\hline Ekol & 0,2586 & 0,0425 & 0,2380 & 0,1774 & 0,2763 \\
\hline Netlog & 0,2473 & 0,2272 & 0,1609 & 0,0923 & 0,2165 \\
\hline Reysaş & 0,0471 & 0,2188 & 0,1847 & 0,0940 & 0,0049 \\
\hline Horoz & 0,0677 & 0,0516 & 0,0391 & 0,0478 & 0,0123 \\
\hline Borusan & 0,2199 & 0,2343 & 0,2224 & 0,2961 & 0,4034 \\
\hline Alışan & 0,0483 & 0,0350 & 0,0589 & 0,0193 & 0,0106 \\
\hline \multicolumn{6}{|c|}{2016} \\
\hline Mars & 0,1046 & 0,1696 & 0,0815 & 0,2329 & 0,1373 \\
\hline Ekol & 0,2538 & 0,1063 & 0,2187 & 0,1599 & 0,3135 \\
\hline Netlog & 0,2485 & 0,2127 & 0,1771 & 0,1141 & 0,4086 \\
\hline Reysaş & 0,0512 & 0,1911 & 0,1841 & 0,1243 & 0,0073 \\
\hline Horoz & 0,0804 & 0,0561 & 0,0417 & 0,0472 & 0,0243 \\
\hline Borusan & 0,2108 & 0,1950 & 0,2356 & 0,2954 & 0,0847 \\
\hline Alışan & 0,0506 & 0,0692 & 0,0613 & 0,0263 & 0,0243 \\
\hline \multicolumn{6}{|c|}{2015} \\
\hline Mars & 0,1017 & 0,1319 & 0,0734 & 0,2092 & 0,1607 \\
\hline Ekol & 0,2366 & 0,1213 & 0,2051 & 0,1621 & 0,1982 \\
\hline Netlog & 0,2456 & 0,1677 & 0,1845 & 0,1310 & 0,4818 \\
\hline Reysaş & 0,0531 & 0,2351 & 0,2066 & 0,1952 & 0,0081 \\
\hline Horoz & 0,0868 & 0,0569 & 0,0393 & 0,0089 & 0,0313 \\
\hline Borusan & 0,2208 & 0,2117 & 0,2411 & 0,2748 & 0,0887 \\
\hline Alışan & 0,0556 & 0,0753 & 0,0500 & 0,0188 & 0,0312 \\
\hline
\end{tabular}

Measurement of the entropy value $\left(e_{j}\right)$ for all criteria is expressed after normalized the decision matrix by using determined entropy values $\left(P_{i j} l n P_{i j}\right)$. Then, the degree of divergence $\left(d_{j}\right)$ and the objective weight $\left(w_{j}\right)$ for each criterion are measured, respectively. All the values of the entropy value, the degree of divergence, and the objective weight between the years of 2015 and 2019 are reported on Table 4. 
H. H. Erdoğan - G. Kırbaç 13/2 (2021) 1093-1106

Table 4. Entropy Values and Objective Weights

\begin{tabular}{|c|c|c|c|c|c|}
\hline & Net Sales & EBIT & Total Assets & Total Equity & Export \\
\hline \multicolumn{6}{|c|}{2019} \\
\hline $\mathbf{e}_{j}$ & 0,8799 & 0,8680 & 0,9172 & 0,8335 & 0,6669 \\
\hline $\mathbf{d}_{j}$ & 0,1201 & 0,1320 & 0,0828 & 0,1665 & 0,3331 \\
\hline $\mathbf{w}_{j}$ & 0,1439 & 0,1582 & 0,0992 & 0,1995 & 0,3992 \\
\hline \multicolumn{6}{|c|}{2018} \\
\hline $\mathbf{e}_{\mathbf{j}}$ & 0,7505 & 0,7284 & 0,8084 & 0,6927 & 0,2959 \\
\hline $\mathbf{d}_{\mathbf{j}}$ & 0,2495 & 0,2716 & 0,1916 & 0,3073 & 0,7041 \\
\hline $\mathbf{w}_{\mathbf{j}}$ & 0,1447 & 0,1575 & 0,1111 & 0,1782 & 0,4084 \\
\hline \multicolumn{6}{|c|}{2017} \\
\hline $\mathbf{e}_{\mathbf{j}}$ & 0,8968 & 0,8889 & 0,9252 & 0,8661 & 0,7076 \\
\hline$d_{j}$ & 0,1032 & 0,1111 & 0,0748 & 0,1339 & 0,2924 \\
\hline $\mathbf{w}_{\mathrm{j}}$ & 0,1443 & 0,1553 & 0,1046 & 0,1872 & 0,4087 \\
\hline \multicolumn{6}{|c|}{2016} \\
\hline $\mathbf{e}_{j}$ & 0,9067 & 0,9507 & 0,9245 & 0,8938 & 0,7336 \\
\hline $\mathrm{d}_{\mathrm{j}}$ & 0,0933 & 0,0493 & 0,0755 & 0,1062 & 0,2664 \\
\hline $\mathbf{w}_{j}$ & 0,1580 & 0,0835 & 0,1278 & 0,1798 & 0,4509 \\
\hline \multicolumn{6}{|c|}{2015} \\
\hline $\mathbf{e}_{j}$ & 0,9149 & 0,9505 & 0,9118 & 0,8628 & 0,7384 \\
\hline $\mathbf{d}_{\mathbf{j}}$ & 0,0851 & 0,0495 & 0,0882 & 0,1372 & 0,2616 \\
\hline $\mathbf{w}_{\mathrm{j}}$ & 0,1369 & 0,0797 & 0,1419 & 0,2207 & 0,4209 \\
\hline
\end{tabular}

To sum up, the evaluation criteria of Export was determined as the best performance criteria affecting the logistics companies' performance with the highest objective weights obtained from Entropy Method. Therefore, it can be reached from the results that Total Equity, EBIT and Net Sales follow the amount of Export, respectively, for the years of 2019, 2018 and 2017. Additionally, Total Assets is the least affecting performance evaluation criteria for the logistics companies between the years of 2017-2019. However, it is observed that while the amount of Export mostly affects the financial performance, EBIT is least effective for both 2016 and 2015. Even if Export is the best performance evaluation criteria for all the years, the objective weight is decreasing from 2016 to 2019.

\subsection{WASPAS Results}

After determining objective weights of the evaluation criteria through Entropy Method, to rank the companies based on their performances WASPAS Method is used. The related normalized decision matrix of seven logistics companies and five evaluation criteria is exhibited on Table 5.

Table 5. Normalized Decision Matrix

\begin{tabular}{llllll}
\hline & Net Sales & EBIT & Total Assets & Total Equity & Export \\
\hline \multicolumn{7}{c}{$\mathbf{2 0 1 9}$} & & \\
\hline Mars & 0,3860 & 0,6210 & 0,4438 & 1,0000 & 0,1929 \\
\hline Ekol & 0,7070 & 0,1818 & 0,8958 & 0,4818 & 0,7577 \\
\hline
\end{tabular}


H. H. Erdoğan - G. Kirbaç 13/2 (2021) 1093-1106

\begin{tabular}{|c|c|c|c|c|c|}
\hline Netlog & 1,0000 & 1,0000 & 1,0000 & 0,4689 & 1,0000 \\
\hline Reysaş & 0,1401 & 0,5873 & 0,4544 & 0,0652 & 0,0257 \\
\hline Horoz & 0,1639 & 0,0655 & 0,1570 & 0,1015 & 0,0424 \\
\hline Borusan & 0,5338 & 0,2458 & 0,7574 & 0,7862 & 0,1262 \\
\hline Alışan & 0,1536 & 0,2529 & 0,2063 & 0,1187 & 0,0335 \\
\hline \multicolumn{6}{|c|}{2018} \\
\hline Ekol & 1,0000 & 0,3012 & 1,0000 & 1,0000 & 1,0000 \\
\hline Reysaş & 0,1626 & 1,0000 & 0,5413 & 0,1317 & 0,0195 \\
\hline Horoz & 0,1950 & 0,0984 & 0,1224 & 0,2157 & 0,0465 \\
\hline Alışan & 0,1943 & 0,1590 & 0,2158 & 0,1161 & 0,0379 \\
\hline \multicolumn{6}{|c|}{2017} \\
\hline Mars & 0,4297 & 0,8133 & 0,4032 & 0,9229 & 0,1888 \\
\hline Ekol & 1,0000 & 0,1815 & 1,0000 & 0,5990 & 0,6849 \\
\hline Netlog & 0,9564 & 0,9696 & 0,6758 & 0,3118 & 0,5366 \\
\hline Reysaş & 0,1823 & 0,9338 & 0,7759 & 0,3174 & 0,0120 \\
\hline Horoz & 0,2616 & 0,2202 & 0,1641 & 0,16154 & 0,0304 \\
\hline Borusan & 0,8504 & 1,0000 & 0,9343 & 1,0000 & 1,0000 \\
\hline Alışan & 0,1868 & 0,1495 & 0,2473 & 0,0650 & 0,0262 \\
\hline \multicolumn{6}{|c|}{2016} \\
\hline Mars & 0,4121 & 0,7973 & 0,3459 & 0,7885 & 0,3360 \\
\hline Ekol & 1,0000 & 0,4997 & 0,9282 & 0,5412 & 0,7678 \\
\hline Netlog & 0,9793 & 1,0000 & 0,7512 & 0,3863 & 1,0000 \\
\hline Reysaş & 0,2019 & 0,8987 & 0,7815 & 0,4209 & 0,0177 \\
\hline Horoz & 0,3168 & 0,2637 & 0,1770 & 0,1597 & 0,0595 \\
\hline Borusan & 0,8307 & 0,9167 & 1,0000 & 1,0000 & 0,2072 \\
\hline Alışan & 0,1995 & 0,3254 & 0,2600 & 0,0888 & 0,0595 \\
\hline \multicolumn{6}{|c|}{2015} \\
\hline Mars & 0,4139 & 0,5612 & 0,3044 & 0,7614 & 0,3335 \\
\hline Ekol & 0,9632 & 0,5158 & 0,8506 & 0,5899 & 0,4115 \\
\hline Netlog & 1,0000 & 0,7134 & 0,7650 & 0,4765 & 1,0000 \\
\hline Reysaş & 0,2163 & 1,0000 & 0,8568 & 0,71051 & 0,0167 \\
\hline Horoz & 0,3532 & 0,2420 & 0,1630 & 0,0323 & 0,0651 \\
\hline Borusan & 0,8989 & 0,9004 & 1,0000 & 1,0000 & 0,1841 \\
\hline Alışan & 0,2262 & 0,3203 & 0,2073 & 0,0683 & 0,0647 \\
\hline
\end{tabular}

The total relative importance of the alternatives based on the weighted sum model (WSM) and weighted product model (WPM) is seen from the Table 6 and Table 7, respectively.

Table 6. Normalized Weighted Matrix (WSM)

\begin{tabular}{llllll}
\hline & Net Sales & EBIT & Total Assets & Total Equity & Export \\
\hline \multicolumn{7}{c}{$\mathbf{2 0 1 9}$} \\
Mars & 0,0772 & 0,1242 & 0,0888 & 0,2000 & 0,0386 \\
\hline Ekol & 0,1414 & 0,0364 & 0,1792 & 0,0964 & 0,1515 \\
\hline
\end{tabular}


H. H. Erdoğan - G. Kirbaç 13/2 (2021) 1093-1106

\begin{tabular}{|c|c|c|c|c|c|}
\hline Netlog & 0,2000 & 0,2000 & 0,2000 & 0,0938 & 0,2000 \\
\hline Reysaş & 0,0280 & 0,1175 & 0,0909 & 0,0130 & 0,0051 \\
\hline Horoz & 0,0328 & 0,0131 & 0,0314 & 0,0203 & 0,0085 \\
\hline Borusan & 0,1068 & 0,0492 & 0,1515 & 0,1572 & 0,0252 \\
\hline Alışan & 0,0307 & 0,0506 & 0,0413 & 0,0237 & 0,0067 \\
\hline \multicolumn{6}{|c|}{2018} \\
\hline Ekol & 0,2000 & 0,0603 & 0,2000 & 0,2000 & 0,2000 \\
\hline Reysaş & 0,0325 & 0,2000 & 0,1083 & 0,0264 & 0,0039 \\
\hline Horoz & 0,0390 & 0,0197 & 0,0245 & 0,0431 & 0,0093 \\
\hline Alışan & 0,0389 & 0,0318 & 0,0432 & 0,0232 & 0,0076 \\
\hline \multicolumn{6}{|c|}{2017} \\
\hline Mars & 0,0859 & 0,1627 & 0,0806 & 0,1846 & 0,0378 \\
\hline Ekol & 0,2000 & 0,0363 & 0,2000 & 0,1198 & 0,1370 \\
\hline Netlog & 0,1913 & 0,1939 & 0,1352 & 0,0624 & 0,1073 \\
\hline Reysaş & 0,0365 & 0,1868 & 0,1552 & 0,0635 & 0,0024 \\
\hline Horoz & 0,0523 & 0,0440 & 0,0328 & 0,0323 & 0,0061 \\
\hline Borusan & 0,1701 & 0,2000 & 0,1869 & 0,2000 & 0,2000 \\
\hline Alışan & 0,0374 & 0,0299 & 0,0495 & 0,0130 & 0,0053 \\
\hline \multicolumn{6}{|c|}{2016} \\
\hline Mars & 0,0824 & 0,1595 & 0,0692 & 0,1577 & 0,0672 \\
\hline Ekol & 0,2000 & 0,0999 & 0,1856 & 0,1082 & 0,1535 \\
\hline Netlog & 0,1959 & 0,2000 & 0,1503 & 0,0773 & 0,2000 \\
\hline Reysaş & 0,0404 & 0,1797 & 0,1563 & 0,0842 & 0,0036 \\
\hline Horoz & 0,0634 & 0,0527 & 0,0354 & 0,0319 & 0,0119 \\
\hline Borusan & 0,1662 & 0,1834 & 0,2000 & 0,2000 & 0,0414 \\
\hline Alışan & 0,0399 & 0,0651 & 0,0520 & 0,0178 & 0,0119 \\
\hline \multicolumn{6}{|c|}{2015} \\
\hline Mars & 0,0828 & 0,1122 & 0,0609 & 0,1523 & 0,0667 \\
\hline Ekol & 0,1926 & 0,1032 & 0,1701 & 0,1180 & 0,0823 \\
\hline Netlog & 0,2000 & 0,1427 & 0,1530 & 0,0953 & 0,2000 \\
\hline Reysaş & 0,0433 & 0,2000 & 0,1714 & 0,1421 & 0,0033 \\
\hline Horoz & 0,0707 & 0,0484 & 0,0326 & 0,0065 & 0,0130 \\
\hline Borusan & 0,1798 & 0,1801 & 0,2000 & 0,2000 & 0,0368 \\
\hline Alişan & 0,0452 & 0,0641 & 0,0415 & 0,0137 & 0,0129 \\
\hline
\end{tabular}

Table 7 also provides a joint generalized criterion for determining the values of total relative importance for all the considered performance alternatives for a $\lambda$ value of 0.5 . As mentioned earlier, the alternatives are ranked based on the $Q_{i}$ values and the highest $Q_{i}$ value is an indicator of the best alternative with respect to a set of decision criteria. Accordingly, it is observed that while the company of Netlog is the best alternative in 2019, 2016 and 2015, the company of Borusan exhibits the best performance in 2017. Because the financial data of these companies is not published in our data source on the Fortune Turkey list in 2018, WASPAS scores are not recorded for Mars, Netlog, and Borusan, and thus, the entire ranking order of the alternatives based on their financial performances is Ekol, Reysaş, Alışan, and Horoz, respectively, in 2018. The company with the worst performance is Horoz in 2019, 2018 and 2017, Alışan in 2016 and 2015.

Table 7. Normalized Weighted Matrix (WPM)

\begin{tabular}{lllllllll}
\hline Net & & Total & Total & & & & \\
Sales & EBIT & Assets & Equity & Export & $Q_{i}^{(1)}$ & $Q_{i}^{(2)}$ & $Q_{i}$ \\
\hline
\end{tabular}


H. H. Erdoğan - G. Kirbaç 13/2 (2021) 1093-1106

\begin{tabular}{|c|c|c|c|c|c|c|c|c|c|}
\hline \multicolumn{10}{|c|}{2019} \\
\hline Mars & 0,8266 & 0,9091 & 0,8500 & 1,0000 & 0,7196 & 0,5287 & 0,4597 & 0,4942 & 3 \\
\hline Ekol & 0,9330 & 0,7111 & 0,9782 & 0,8641 & 0,9460 & 0,6048 & 0,5305 & 0,5677 & 2 \\
\hline Netlog & 1,0000 & 1,0000 & 1,0000 & 0,8594 & 1,0000 & 0,8938 & 0,8594 & 0,8766 & 1 \\
\hline Reysaş & 0,6750 & 0,8990 & 0,8541 & 0,5792 & 0,4809 & 0,2545 & 0,1443 & 0,1994 & 5 \\
\hline Horoz & 0,6965 & 0,5798 & 0,6906 & 0,6329 & 0,5315 & 0,1061 & 0,0938 & 0,0999 & 7 \\
\hline Borusan & 0,8820 & 0,7553 & 0,9459 & 0,9530 & 0,6610 & 0,4899 & 0,3970 & 0,4434 & 4 \\
\hline Alışan & 0,6875 & 0,7596 & 0,7293 & 0,6529 & 0,5069 & 0,1530 & 0,1260 & 0,1395 & 6 \\
\hline \multicolumn{10}{|c|}{2018} \\
\hline Ekol & 1,0000 & 0,7867 & 1,0000 & 1,0000 & 1,0000 & 0,8603 & 0,7866 & 0,8234 & 1 \\
\hline Reysaş & 0,6954 & 1,0000 & 0,8845 & 0,6668 & 0,4551 & 0,3711 & 0,1866 & 0,2788 & 2 \\
\hline Horoz & 0,7211 & 0,6290 & 0,6570 & 0,7358 & 0,5415 & 0,1356 & 0,1187 & 0,1272 & 4 \\
\hline Alışan & 0,7206 & 0,6923 & 0,7359 & 0,6502 & 0,5197 & 0,1447 & 0,1240 & 0,1343 & 3 \\
\hline \multicolumn{10}{|c|}{2017} \\
\hline Mars & 0,8446 & 0,9595 & 0,8339 & 0,9841 & 0,7165 & 0,5516 & 0,4764 & 0,5140 & 4 \\
\hline Ekol & 1,0000 & 0,7109 & 1,0000 & 0,9026 & 0,9271 & 0,6931 & 0,5948 & 0,6439 & 3 \\
\hline Netlog & 0,9911 & 0,9939 & 0,9246 & 0,7921 & 0,8829 & 0,6901 & 0,6369 & 0,6635 & 2 \\
\hline Reysaş & 0,7115 & 0,9864 & 0,9505 & 0,7949 & 0,4131 & 0,4443 & 0,2190 & 0,3317 & 5 \\
\hline Horoz & 0,7648 & 0,7389 & 0,6967 & 0,6945 & 0,4972 & 0,1676 & 0,1359 & 0,1518 & 6 \\
\hline Borusan & 0,9681 & 1,0000 & 0,9865 & 1,0000 & 1,0000 & 0,9570 & 0,9550 & 0,9560 & 1 \\
\hline Alışan & 0,7150 & 0,6838 & 0,7563 & 0,5790 & 0,4830 & 0,1350 & 0,1033 & 0,1192 & 7 \\
\hline \multicolumn{10}{|c|}{2016} \\
\hline Mars & 0,8375 & 0,9557 & 0,8087 & 0,9536 & 0,8040 & 0,5359 & 0,4962 & 0,5161 & 4 \\
\hline Ekol & 1,0000 & 0,8705 & 0,9852 & 0,8845 & 0,9484 & 0,7473 & 0,7193 & 0,7333 & 3 \\
\hline Netlog & 0,9958 & 1,0000 & 0,9445 & 0,8268 & 1,0000 & 0,8235 & 0,7776 & 0,8006 & 1 \\
\hline Reysaş & 0,7262 & 0,9789 & 0,9519 & 0,8411 & 0,4467 & 0,4642 & 0,2542 & 0,3592 & 5 \\
\hline Horoz & 0,7946 & 0,7660 & 0,7072 & 0,6929 & 0,5688 & 0,1954 & 0,1696 & 0,1825 & 6 \\
\hline Borusan & 0,9636 & 0,9828 & 1,0000 & 1,0000 & 0,7299 & 0,7909 & 0,6912 & 0,7412 & 2 \\
\hline Alışan & 0,7244 & 0,7989 & 0,7638 & 0,6163 & 0,5688 & 0,1867 & 0,1549 & 0,1708 & 7 \\
\hline \multicolumn{10}{|c|}{2015} \\
\hline Mars & 0,8383 & 0,8909 & 0,7883 & 0,9470 & 0,8029 & 0,4749 & 0,4476 & 0,4612 & 4 \\
\hline Ekol & 0,9925 & 0,8760 & 0,9682 & 0,8998 & 0,8373 & 0,6662 & 0,6341 & 0,6502 & 3 \\
\hline Netlog & 1,0000 & 0,9347 & 0,9479 & 0,8622 & 1,0000 & 0,7910 & 0,7638 & 0,7774 & 1 \\
\hline Reysaş & 0,7363 & 1,0000 & 0,9696 & 0,9339 & 0,4413 & 0,5601 & 0,2941 & 0,4271 & 5 \\
\hline Horoz & 0,8121 & 0,7530 & 0,6957 & 0,5035 & 0,5790 & 0,1712 & 0,1240 & 0,1475 & 7 \\
\hline Borusan & 0,9789 & 0,9792 & 1,0000 & 1,0000 & 0,7129 & 0,7967 & 0,6833 & 0,7400 & 2 \\
\hline Alışan & 0,7429 & 0,7964 & 0,7300 & 0,5847 & 0,5784 & 0,1774 & 0,1460 & 0,1617 & 6 \\
\hline
\end{tabular}

A more generalized analysis for determining the total relative importance of the alternatives is conducted and the results are presented on Table 8. Also, Table 8 shows the effect of varying values of $\lambda$ on the performance scores and rankings of seven logistics companies from 2015 to 2019. It is seen from the table that different $\lambda$ values almost do not affect the rankings of the best and the worst alternatives and a better ranking performance is estimated for the higher value of $\lambda$. Accordingly, WASPAS Method behaves like the WSM method, because when the value of $\lambda$ is equal to ' 1 ', it is transformed to the weighted sum model (WSM).

Table 8 also exhibits that while the company of Netlog is the best alternative in 2019, 2016 and 2015, the company of Borusan exhibits the best performance in 2017. The company with the worst performance is Horoz in 2019, 2018 and 2015, Alışan in 2017 and 2016. Thus, it can be said that the WASPAS rankings of the logistics companies virtually match the WSM rankings, supporting the study of Chakraborty and Zavadskas (2014). 
H. H. Erdoğan - G. Kirbaç 13/2 (2021) 1093-1106

Table 8. Effect of $\lambda$ on Ranking Performance

\begin{tabular}{|c|c|c|c|c|c|c|c|c|c|c|c|c|}
\hline & $=0$ & & 2 & 3 & 4 & & 6 & 7 & 8 & 9 & $\lambda=1$ & \\
\hline \multicolumn{13}{|c|}{2019} \\
\hline Mars & 0,4597 & 0,4666 & 0,4735 & 0,4804 & 0,4873 & 0,4942 & 0,5011 & 0,5080 & 150 & 5218 & 0,5287 & 3 \\
\hline Ekol & 305 & 5379 & 0,5454 & 0,5528 & 0,5602 & 0,5677 & 0,5751 & 0,5825 & 0,5899 & 5974 & 0,6048 & 2 \\
\hline Netlog & 8594 & 8629 & 0,8663 & 0,8697 & 0,8732 & 0,8766 & 0,8800 & 0,8835 & 0,8869 & 0,8903 & 0,8938 & 1 \\
\hline & 1443 & 0,1554 & 0,1664 & 0,1774 & 0,1884 & 0,1994 & 0,2105 & 0,2215 & 0,2325 & 0,2435 & 0,2545 & 5 \\
\hline & 38 & 0,0950 & 0,0963 & 0,0975 & 7 & 0,0999 & 0,1012 & 0,1024 & 0,1036 & 0,1049 & 0,1060 & 7 \\
\hline & 70 & 0,4 & & 19 & 0,4341 & 134 & 27 & 620 & 713 & 806 & 899 & 4 \\
\hline & 260 & 87 & 14 & 41 & 368 & 0,1395 & 422 & 449 & 1476 & 503 & 0,1529 & 6 \\
\hline \multicolumn{13}{|c|}{2018} \\
\hline $\mathrm{E}$ & 0,7867 & 0,9860 & 0,8014 & 0,8088 & 0,8160 & 0,8235 & 0,8308 & 0,8382 & 0,8455 & 0,8529 & 0,8603 & 1 \\
\hline aş & 0,1867 & 0,9371 & 0,2235 & 0,2420 & 0,2604 & 0,2789 & 0,2973 & 0,3157 & 0,3342 & 0,3526 & 0,3711 & 2 \\
\hline & & & & & & 272 & & & & & & 4 \\
\hline & & & & & & & & & & & & 3 \\
\hline \multicolumn{13}{|c|}{2017} \\
\hline & & 39 & 4 & 9 & 064 & 0 & & & & & 5 & 4 \\
\hline & & & & & & & & & & & & 3 \\
\hline Netlog & 0,6370 & 0,6423 & 0,6476 & 0,6529 & 0,6582 & 0,6635 & 0,6688 & 41 & 0,6794 & 0,6847 & 0,6900 & 2 \\
\hline & & 0,2415 & 0,2641 & 0,2866 & 0,3 & 0,3316 & 0,3542 & 0,3767 & 992 & 217 & 0,4443 & 5 \\
\hline & & & & & & & & & & & & 6 \\
\hline & 0,9551 & 0,9552 & 0,9554 & 0,9556 & 0,9558 & 0,9560 & 62 & 63 & 0,9565 & 567 & 0,9569 & 1 \\
\hline & 01034 & 0,1065 & 0,1097 & 0,1128 & 0,1160 & 0,1192 & 0,1224 & 0,1255 & 0,1286 & 0,1318 & 0,1350 & 7 \\
\hline \multicolumn{13}{|c|}{2016} \\
\hline $\mathrm{M}$ & 0,4963 & 0,5002 & 0,5042 & 0,5081 & 0,5121 & 0,5161 & 0,5201 & 0,5240 & 0,5280 & 0,5319 & 0,5359 & 4 \\
\hline & 0,7194 & 0,7221 & 0,7249 & 0,7277 & 0,7305 & 0,7333 & 0,7361 & 0,7389 & 0,7417 & 0,7445 & 0,7472 & 2 \\
\hline & 0,7777 & 0,7822 & 0,7868 & 0,7913 & 59 & & & & 43 & 88 & 234 & 1 \\
\hline & 0,2542 & 0,2752 & 0,2962 & 0,3172 & & 0,3591 & 0,3802 & & 0,4221 & 0,4431 & 0,4641 & 5 \\
\hline $\mathbf{H}$ & 0,1697 & 0,1722 & 0,1748 & 0,1773 & 0,1799 & 0,1825 & 0,1851 & 0,1876 & 0,1902 & 0,1927 & 0,1953 & 6 \\
\hline & & & & 0,7211 & 0,7311 & & & & 710 & 309 & 909 & 3 \\
\hline & 0,1550 & 0,1581 & 0,1612 & 0,1644 & 0,1676 & 0,1708 & 0,1740 & 0,1771 & 0,1803 & 0,1834 & 0,1866 & 7 \\
\hline \multicolumn{13}{|c|}{2015} \\
\hline Mars & 0,4476 & & 0,4530 & 0,4557 & & 0,4612 & 0,4640 & 0,4667 & 0,4694 & 0,4721 & 0,4749 & 4 \\
\hline & 0,6342 & 0,6373 & 0,6405 & 0,6437 & 0,6469 & 0,6501 & 0,6534 & 0,6566 & 0,6598 & 0,6630 & 0,6662 & 3 \\
\hline & 0,7639 & 0,7666 & 0,7693 & 0,7720 & 0,7747 & 0,7774 & 0,7802 & 0,7828 & 0,7855 & 0,7883 & 0,7910 & 1 \\
\hline Reysaş & & 0,3207 & 0,3473 & 0,3739 & & 0,4271 & 0,4537 & & 0,5069 & & 0,5600 & 5 \\
\hline Horoz & 0,1240 & 0,1287 & 0,1334 & 0,1381 & 0,1428 & 0,1475 & 0,1523 & 0,1570 & 0,1617 & 0,1664 & 0,1711 & 7 \\
\hline Borusan & 0,6834 & 0,6947 & 0,7060 & 0,7173 & 0,7287 & 0,7400 & 0,7514 & 0,7626 & 0,7740 & 0,7853 & 0,7966 & 2 \\
\hline Alışan & 0,1460 & 0,1491 & 0,1523 & 0,1554 & 0,1585 & 0,1617 & 0,1649 & 0,1679 & 0,1711 & 0,1742 & 0,1773 & 6 \\
\hline
\end{tabular}

\section{DISCUSSION AND CONCLUSION}

The dimensions of competition in today's trade are undeniably high. Increasing logistics and supply chain performance also has an important share in this commercial competitive environment. Financial ratios are one of the measurement indicators used in determining the logistics performance of the companies.

In this study, the financial performance of the logistics companies and supply chain providers (Mars, Ekol, Netlog, Reysaş, Borusan, Horoz, Alışan) was evaluated between the years of 2015 and 2019 by utilizing multicriteria decision-making techniques (Entropy and WASPAS methods). As financial performance measurement 
indicators, net sales, earnings before interest and taxes (EBIT), total assets, total equity, and the amount of export were selected and obtained from the official website of Fortune Turkey.

Firstly in the study, Entropy Method was used for determining the best performance criteria affecting the companies' performance. The Export was determined as the best performance criteria affecting the logistics companies' performance for all the years between 2015 and 2019. Undoubtedly, the importance of export has a great place not only for logistics companies but also for all businesses. The logistics companies included in the study offer services like Third and Fourth Party Logistics (3PL and 4PL) service providers in the market. These services can be listed as distribution, transportation, production and operation management, warehousing, packaging, inventory management, etc. While logistics companies offer all these operations to the businesses and their supply chain operations that they serve, they also participate in the export processes of these companies. In this way, they have a chance to increase their export amounts. In addition, when logistics companies increase their export amounts within the scope of financial performance measurement, they add value to their companies in many different ways. For instance, logistics companies acquire foreign capital with the increase in exports and have the opportunity to direct this to investment. On the other hand, Total Assets is the least affecting performance evaluation criteria between the years of 2017-2019 and EBIT is the least affecting performance evaluation criteria for both the year 2015 and 2016. An increase in the total assets certainly contributes to businesses, but when considered in terms of logistics companies, the added value of the increase in exports is higher than the increase in total assets.

WASPAS Method is then used to rank the companies based on their performances. In the study according to this method, Netlog is the best alternative in the year of 2015, 2016 and 2019. Therefore, Borusan is also the best alternative in the year of 2017. When these results are examined, Netlog increased its net sales by $131 \%$ compared to the previous year and reached 4.7 billion TL. The company achieved significant success by netting $65 \%$ of its net sales income from exports. At the same time, Netlog is selected as Turkey's logistics sector leader at many different indexes and platforms. Netlog is also located in the first row for many years at Turkey's 500 Largest Exporter of Services research according to Freight Transport and Logistics Services category. On the other hand, Borusan is another leading company in the sector and it operates in the automotive logistics, warehouse management, supply chain solutions, and international transportation fields. Borusan provides a competitive advantage by serving the sector with the digital platforms which it has established within its own structure. However, Horoz Logistics has the worst performance in the year of 2015, 2018 and 2019. Also, Alşan Logistics has the worst performance in the year of 2016 and 2017. Considering the companies of Horoz and Alışan Logistics, it can be stated that their market shares are lower than other the best alternative companies. At the same time, it can be said that these companies have fewer warehouse and vehicle infrastructures compared to other companies.

As conclusion, the results obtained by using these methods in our study, the sectoral data, and evaluations of logistics companies match with each other. Hence, it is believed that this study will be useful for the companies who trade in different sectors and will contribute to the finance literature as a reference for further studies. In this context, because of their quite comprehensive natures, both Entropy and WASPAS methods can be conducted to any manufacturing-related decision-making processes.

\section{REFERENCES}

Akçakanat, Ö., Eren, H., Aksoy, E. and Ömürbek, V. (2018) .Bankacılık Sektöründe Entropi ve WASPAS Yöntemleri ile Performans Değerlendirmesi, Suleyman Demirel University the Journal of Faculty of Economics and Administrative Sciences, 22(2), 285-300.

Ayçin, E. and Güçlü, P. (2020). BIST Ticaret Endeksinde Yer Alan İşletmelerin Finansal Performanslarının Entropi ve MAIRCA Yöntemleri ile Değerlendirilmesi, The Journal of Accounting and Finance, 85, 287-312. 
H. H. Erdoğan - G. Kırbaç 13/2 (2021) 1093-1106

Bağcl, H. and Kaygın, C. Y. (2020). The Financial Performance Measurement of the Companies Listed in the BIST Holding and Investment Index by the MCDM Methods, The Journal of Accounting and Finance, 87, 301-324.

Bağcl, H. and Yiğiter, Ş. Y. (2019). BİST'te Yer Alan Enerji Şirketlerinin Finansal Performansının SD ve WASPAS Yöntemleriyle Ölçülmesi, Bingöl University Journal of Social Sciences Institute, 9(18), 877-898.

Beamon, B. M. (1999). Measuring Supply Chain Performance. International Journal of Operations and Production Management, 19(3), 275-292.

Chakraborty, S. and Zavadskas, E. K. (2014). Applications of WASPAS Method in Manufacturing Decision Making, Informatica, 25(1), 1-20.

Christopher, M. (2011). Logistics and Supply Chain Management: Creating Value-Adding Networks, 4 ed., Pearson UK.

Ghorabaee, M. K., Amiri, M., Zavadskas, E. K. and Antuchevičienė, J. (2017). Assessment of Third-Party Logistics Providers Using a CRITIC-WASPAS Approach with Interval Type-2 Fuzzy Sets, Transport, 32(1), 66-78.

Gunasekaran, A., Patel, C., \& Tirtiroglu, E. (2001). Performance Measures and Metrics in a Supply Chain Environment. International Journal of Operations and Production Management, 21(1-2), 71-87.

Gunasekaran, A. and Kobu, B. (2007). Performance Measures and Metrics in Logistics and Supply Chain Management: A Review of Recent Literature (1995-2004) for Research and Applications, International Journal of Production Research, 45(12), 2819-2840.

Özaydın, G., Kayahan Karakul, A. (2021). Entropi Tabanlı MAUT, SAW ve EDAS Yöntemleri ile Finansal Performans Değerlendirmesi, Süleyman Demirel Üniversitesi İktisadi ve İdari Bilimler Fakültesi Dergisi, 26 (1), 13-29.

Shannon, C. E. (1948). A Mathematical Theory of Communication. Bell System Technical Journal, 27, 379-423.

Skowron-Grabowska, B. (2009). Performance Measurement in Logistics Centers, Advanced Logistic Systems, 3(1), 213-218.

Strouhal, J., Stamfestova, P., Kljucnikov, A. and Vincurova, Z. (2018). Different Approaches to the EBIT Construction and Their Impact on Corporate Financial Performance based on the Return on Assets: Some Evidence from Czech Top100 Companies, Journal of Competitiveness, 10(1), 144-154.

Ulutaş, A. (2019). Entropi Tabanlı EDAS Yöntemi ile Lojistik Firnalarının Performans Analizi, International Journal of Economics and Administrative Studies, 23, 53-66.

Ural, M., Demireli, E. and Özçalık, S.G. (2018). Kamu Bankalarında Performans Analizi: Entropi ve WASPAS Yöntemleri ile Bir Uygulama, Pamukkale University Journal of Social Sciences Institute,31, 129-141.

$\mathrm{Wu}$, J., Sun, J., Liang, L. and Zha, Y. (2011). Determination of Weights for Ultimate Cross Efficiency Using Shannon Entropy, Expert Systems with Applications, 38, 5162-5165.

Xiong, L., Zhong, S., Liu, S., Zhang, X. and Yanfeng, L.(2020). An Approach for Resilient-Green Supplier Selection Based on WASPAS, BWM, and TOPSIS under Intuitionistic Fuzzy Sets, Mathematical Problems in Engineering, 2020, 1-18.

Zavadskas, E.K., Turskis, Z. and Antucheviciene, J. (2012). Optimization of Weighted Aggregated Sum Product Assessment, Electronics and Electrical Engineering, 6(122), 3-6.

Zolfani, S. H., Aghdaie, M. H., Derakhti, A., Zavadskas, E. K. and Varzandeh, M. H. M. (2013). Decision Making on Business Issues with Foresight Perspective; An Application of New Hybrid MCDM Model in Shopping Mall Locating, Expert Systems with Applications, 40(17), 7111-7121. 